\title{
PERJUANGAN SEORANG PELARIAN PERANG: LEE HAU SHIK SEMASA PENDUDUKAN TENTERA JEPUN, 1941-1945
}

\author{
Tan Miau Ing
}

\begin{abstract}
Tun Lee Hau Shik (H.S. Lee) was founder leader of the Malayan (later Malaysian) Chinese Association (MCA). He helped forged an UMNO-MCA alliance in 1952 that led to the eventual formation of the Alliance Party and was part of the Malayan delegation to London to negotiate for the country's independence. Hong Kong-born and Cambridge-educated, Lee came to Malaya in 1924 to take care of his family business. With wealth acquired from tin mining, a well-to-do family and good educational background, Lee quickly rose to prominence in the Selangor Chinese community. However, Lee who served as the Chief Air Raid Warden of Kuala Lumpur and an influential leader in the anti-Japanese movements in Selangor was forced to leave Malaya during the Japanese invasion. This paper will examine the years he spent in India as a political refugee from Japanese occupation of Malaya and the extent to which the experience of the WWII enabled Lee to transform from a local Chinese leader to a national leader.
\end{abstract}

\section{Pengenalan}

Selepas Perang Dunia Kedua, ramai pemimpin terkemuka yang bekerjasama dengan pihak Jepun semasa Pendudukan Jepun telah dianggap sebagai pengkhianat. Sesetengah daripada mereka telah bersara daripada kehidupan awam sama sekali, sebahagian pula terpaksa berjuang untuk memulihkan semula kedudukan mereka dalam masyarakat. Sistem kepimpinan masyarakat Cina yang selama ini diterajui oleh golongan peniaga atau tauke telah dimusnahkan. Lee Hau Shik yang dihantar oleh pihak British untuk kembali ke Tanah Melayu dari India sebagai 'sponsored civilians' bagi membantu pihak British dalam membangun semula ekonomi dan susunan sosial telah muncul semula sebagai pemimpin masyarakat Cina dalam masa yang singkat. Wakil-wakil daripada persatuan-persatuan Cina telah berkumpul di Selangor Chinese Assembly Hall (SCAH) untuk meraikan kepulangan Lee. Mengapakah Lee yang telah melarikan diri ke India semasa Pendudukan Jepun bukan dianggap sebagai pengecut tetapi mendapat sambutan yang begitu hangat? Dengan menggunakan kertas peribadi H.S. Lee, kertas ini cuba mengkaji pengalaman H.S. Lee di India sebagai pelari perang dan sejauh manakah pengalaman Perang Dunia Kedua membantu mengekalkan kedudukan Lee sebagai pemimpin masyarakat Cina, malah membolehkan beliau berubah daripada seorang peniaga kepada ahli politik yang mengasaskan Malayan Chinese Association (MCA) dan Parti Perikatan serta menyertai dalam gerakan kemerdekaan Tanah Melayu.

\section{Latar Belakang Lee Hau Shik}

Lee Hau Shik atau lebih dikenali sebagai H.S. Lee dilahirkan di Hong Kong pada tahun 1901. Beliau berasal daripada sebuah keluarga cendekiawan yang terkenal di Xinyi, di Provinsi Guangdong, China dan menerima pendidikan di Universiti Cambridge. Beliau tiba di Tanah Melayu pada tahun 1924 dan mewarisi perniagaan keluarganya, Kam Lun Tai yang diasaskan oleh bapanya, Lee Kwai Lam (K.L. Lee). Kam Lun Tai merupakan sebuah syarikat perdagangan sutera yang kemudian berkembang menjadi sebuah syarikat transnasional yang terlibat dalam 
perniagaan agensi buruh, pemilik rumah tumpangan, pengurup mata wang asing dan agensi kiriman wang. Cawangannya boleh didapati di bandar-bandar di China, Hong Kong, Singapura dan Tanah Melayu. Keluarganya juga terlibat dalam perlombongan bijih timah dan lombongnya dikenali sebagai Tai Yau yang bermakna 'dipunyai oleh Kam Lun Tai'. Dengan kekayaan yang diperoleh daripada perusahaan lombong bijih timah di samping latar belakang keluarga yang baik dan pendidikan tinggi yang diterima, Lee muncul sebagai salah seorang pemimpin masyarakat Cina di Selangor yang terkemuka dengan memegang jawatan pengerusi Selangor Chinese Chamber of Commerce (SCCC) dan Selangor Miners' Association (SMA).

Berikutan dengan berlakunya Peristiwa Marco Polo Bridge pada Julai 1937, yang membawa kepada tercetusnya Perang China-Jepun antara tahun 1937 dan 1945 telah membawa kepada kebangkitan semangat nasionalisme dalam kalangan orang Cina termasuk orang Cina seberang laut. Lee yang berpendidikan Barat dan adalah subjek British ${ }^{1}$ juga menunjukkan semangat kebangsaannya kepada negara China. Ini mungkin kerana walaupun Lee dilahirkan di Hong Kong iaitu sebuah tanah jajahan British, beliau telah dibesarkan di kampung halamannya di China dan menerima pendidikan Cina di Guangdong dan Hong Kong sebelum melanjutkan pelajaran ke Cambridge. Beliau menganggap Tanah Melayu adalah tempat mencari nafkah hidup, memandangkan sebahagian besar ahli keluarga Lee masih menetap di China. Tambahan pula, hubungan keluarga Lee dengan parti Kuomintang (KMT) yang mentadbir China pada masa itu adalah begitu rapat, di mana bapanya pernah berkhidmat sebagai setiausaha kepada Jabatan Pentadbiran Sivil Provinsi Guangdong, penasihat kepada Perbandaran Guangzhou dan ahli Perhimpunan Provinsi Guangdong, ${ }^{2}$ sepupunya Lin Yun Gai (1881-1948), merupakan datuk bandar Guangzhou dan bapa saudaranya, Yang Yong Tai adalah pegawai kanan KMT. ${ }^{3}$ Dengan latar belakang ini, tidak hairanlah Lee sama seperti orang Cina seberang laut pada masa itu terlibat secara aktif dalam gerakan anti-Jepun malah, muncul sebagai seorang pemimpin terpengaruh dalam gerakan anti-Jepun di Selangor. Beliau merupakan pengarah urusan bagi The Malayan Chinese Daily News yang dikatakan 'full of anti-Japanese provocative articles' ${ }^{4}$ serta pengerusi Selangor China Relief Fund Committee (SCRFC, Jawatankuasa Tabungan Bantuan China Selangor) dan ahli jawatankuasa Federation of China Relief Fund of the South Seas atau dikenali sebagai Nanqiao Zonghui yang terlibat dalam kutipan derma untuk negara China. Pada masa yang sama Lee juga merupakan ahli jawatankuasa Malaya Patriotic Fund (Dana Patriotik Tanah Melayu) iaitu sebuah dana kebajikan untuk membantu British dalam usaha perang. ${ }^{5}$

Menjelang akhir tahun 1940, ancaman perang semakin dirasai. Sebagai ahli Sanitary Board Kuala Lumpur (majlis perbandaran hari ini), Lee telah dilantik sebagai ahli dalam jawatankuasa Air Raid Precautions (ARP, Pencegahan Serangan Udara) Kuala Lumpur dan akhirnya dilantik sebagai Chief Air Raid Warden (Ketua Warden Serangan Udara) apabila tentera Jepun semakin mendekati Kuala Lumpur. ${ }^{6}$ Lee dipujuk oleh duta China di Tanah Melayu untuk mencari perlindungan di tempat lain. ${ }^{7}$ Dikatakan pihak Jepun telah menawarkan $\$ 60,000$ untuk mendapatkan kepalanya kerana peranan beliau dalam mengetuai tabung bantuan China dan Malaya Patriotic Fund serta sebagai Chief Air Raid Warden Kuala Lumpur. ${ }^{8}$ Dengan bantuan Konsul Jeneral China di Singapura, Lee akhirnya mendapatkan visa ke Burma. Sebuah kapal stim kecil, SS Haiching yang selalunya belayar antara Hong Kong dengan pelabuhanpelabuhan di Swatow dan Amoy, China telah diaturkan untuk menghantar pelarian perang termasuk ke Rangoon. ${ }^{9}$ Mereka bertolak dari Singapura pada 30 Januari 1942, kemudian mengubah laluan pelayaran ke India kerana Rangoon juga diserang oleh tentera Jepun. ${ }^{10}$ 


\section{Kembali ke China, 1942}

Lee dan penumpang lain tiba di Madras (Chennai hari ini) tetapi tidak dibenarkan mendarat dengan alasan bahawa visa mereka adalah untuk Burma. Mereka terpaksa meneruskan perjalanan ke Calcutta yang secara kebetulan pegawai yang bertanggungjawab adalah teman Lee di Cambridge. ${ }^{11}$ Maka, atas jaminan Lee, semua penumpang dibenarkan mendarat. Lee menganggap segala kesukaran ini adalah berpunca daripada pegawai British di Pejabat Pasport Singapura yang sengaja enggan memberikan visa ke India. Sebaliknya, Lee merasa dirinya telah menerima banyak bantuan daripada pihak pegawai China. Dikatakan Lee pernah menerima bantuan daripada Jeneralisimo Chiang Kai Shek yang secara kebetulan sedang menjalankan lawatan rahsianya di India untuk mengeluarkan wang yang disimpan di Bank of China, Singapura. Dalam pertemuan ini, Chiang bercadang kepada Lee untuk mendapatkan latihan ketenteraan bagi membantu dalam penentangan Jepun. Berkemungkinan hasil daripada itu, tercetusnya idea untuk membawa ahli keluarganya ke Chungking.

Tambahan pula, India yang tidak dicerobohi oleh tentera Jepun juga berada dalam keadaan huru-hara. Mogok dan rusuhan sering berlaku untuk memperjuangkan kemerdekaan India dari pihak British. Muslim di India pula menuntut pemisahan dari India dan menubuhkan negara Pakistan. Kejatuhan Burma menambahkan lagi perasaan gelisah dan kebimbangan bahawa India juga akan terjatuh di tangan Jepun. Bandar Calcutta dalam keadaan kacau-bilau, di mana lampu dipadamkan pada waktu malam (blackout), siren disiarkan sebagai latihan persediaan untuk serangan udara. Bom dan risalah dari pihak Jepun juga dijatuhkan di Calcutta.

Ramai pelarian perang dari wilayah lain, terutamanya tanah jajahan British, lebih-lebih lagi mereka yang datang dari Tanah Melayu dan Burma telah berduyun-duyun masuk ke India. ${ }^{12}$ Namun, Tanah Melayu tidak mempunyai wakil rasmi di India apabila pelarian mula tiba di sana. Oleh itu, W.J.K. Stark, seorang bekas pegawai kerajaan British di Tanah Melayu yang menetap di Bangalore telah dilantik bersama dengan dua pembantu untuk melayani keperluan para pelarian dari Tanah Melayu. Tumpuan utama telah diberi kepada pegawai kerajaan dan penduduk Tanah Melayu yang berbangsa Eropah yang ditempatkan di kem pelarian perang dengan pemberian elaun hidup oleh kerajaan. ${ }^{13}$

Jadual 1: Bilangan Pelarian Perang Tanah Melayu di India, ${ }^{a}$ Februari 1945

\begin{tabular}{|c|c|c|c|c|}
\hline & Lelaki & Perempuan & Kanak-kanak & Jumlah \\
\hline Orang India ${ }^{b}$ & 3,630 & 1,240 & - & 4,870 \\
\hline Orang Eropah, Serani dan Yahudi & 315 & 527 & 343 & 1,185 \\
\hline Orang Cina $^{c}$ & 72 & 129 & 172 & 373 \\
\hline Orang Melayu & 32 & 4 & 14 & 50 \\
\hline Lain-lain & 5 & 10 & 5 & 20 \\
\hline Jumlah & 4,054 & 1,910 & 534 & 6,498 \\
\hline
\end{tabular}

Sumber: Memorandum oleh C.D. Ahearne, wakil Pejabat Tanah Jajahan untuk Timur Jauh di India, 13 Feb 1945, CO825/46/11 (55).

Nota:

${ }^{a}$ Angka untuk bangsa lain selain orang India diambil daripada mereka yang berdaftar dengan Office of the Malayan Representative di India. Angka sebenar dijangka lebih ramai. 
b Angka orang India diambil daripada Government of India Evacuees Census Report dan dikatakan jumlah sebenar adalah lebih besar daripada angka yang diberikan. Angka yang berasingan tidak diberi untuk kanak-kanak yang telah dimasukkan dalam angka lelaki dan perempuan.

${ }^{\mathrm{c}}$ Jumlah sebenar mungkin lebih tinggi daripada angka ini. Menurut laporan yang diberi oleh Yuen kepada kerajaan China, di Bombay sahaja sudah terdapat hampir 200 orang Cina dari Tanah Melayu. Mussoorie pula terdapat kira-kira 60 orang (termasuk keluarga Lee dan Chan Wing). Ini tidak termasuk orang Cina di tempat lain di India.

Kesan secara langsung daripada kemasukan pelarian perang adalah masalah perumahan dan inflasi. Bagi menempatkan ahli keluarganya yang berjumlah 19 orang ( 8 orang dewasa dan 11 kanak-kanak), Lee pernah berpindah beberapa kali. Dalam suratnya kepada Chan Kwong Hon, Lee menggambarkan keadaan tempat kediamannya:

My flat is rather small, consisting of 2 bedrooms, one sitting room and one dining room. We have turned the dining room into a bedroom, but all the rooms are very small, much smaller than those at Savitri Villa. My wife and I and the two youngest children have one room, Douglas and three other boys the second one, and $K . S$. and the two girls the third one. The rooms are so small that at present they are all jammed up beds leaving very little empty space in the middle. ${ }^{14}$

Peningkatan bilangan penduduk yang mendadak menyebabkan permintaan terhadap barangan keperluan harian terutamanya makanan meningkat dan kadar inflasi juga melambung tinggi. Keadaan menjadi lebih teruk apabila Bengal dilanda taufan pada akhir tahun 1942 dan menyebabkan berlakunya kebuluran yang berleluasa di mana antara 1943-1944 kira-kira tiga juta orang terbunuh. ${ }^{15}$

Berada dalam keadaan ini, rasa ketidakselamatan amat berleluasa dalam kalangan pelarian perang terutamanya mereka yang datang dengan bekalan wang yang terhad untuk menampung kehidupan di India. Seperti Lee, ramai antara orang Cina dari Tanah Melayu telah meletakkan harapan mereka kepada kerajaan China. Misalnya, seramai 200 pelarian perang Cina dari Tanah Melayu yang tinggal di Bombay telah menghantar petisyen kepada Jeneral Wu untuk meminta bantuan dari kerajaan China. ${ }^{16}$ Kebanyakan daripada mereka meninggalkan Tanah Melayu secara tergesa-gesa dan hanya segelintir daripada mereka yang sempat membawa wang atau barangan berharga apabila berlari dari Tanah Melayu. Sesetengah daripada mereka adalah ahli perniagaan dan golongan profesional tetapi yang lebih ramai adalah golongan wanita dan kanak-kanak. Mereka berharap kerajaan China dapat membantu mereka untuk pulang ke China, serta menyediakan kemudahan perumahan, pekerjaan dan pendidikan untuk kanak-kanak mereka. Tiada catatan selanjutnya tentang kumpulan Cina ini, sama ada permintaan mereka menerima pertimbangan daripada pihak kerajaan China atau tidak.

Lee juga ingin membawa keluarganya kembali ke China. Maka, sebaik sahaja Lee duduk menetap di Mussoorie iaitu sebuah bandar peranginan yang jauh di Banjaran Himalaya, beliau mula mengaktifkan semula rangkaian jaringannya dengan pihak pegawai kerajaan China. Pada masa yang sama Lee juga menulis kepada Kelab Rotary di Dehra Dun untuk menyambung keahliannya dengan kelab dan memperoleh maklumat lanjut tentang mereka yang datang dari 
Kuala Lumpur di India. ${ }^{17}$ Apabila Pejabat Suruhanjaya Republik China di India ditubuhkan di New Delhi pada bulan April 1942, Lee dilaporkan telah mewakili Kesatuan Cina di New Delhi untuk mengalu-alukan ketibaan Pesuruhjaya China yang baru, Shen Shih Hua dengan mengadakan jamuan di Davico's, sebuah restoran di New Delhi. ${ }^{18}$ Walaupun tidak jelas persatuan apakah yang Lee mewakili tetapi ia menunjukkan kemahiran Lee dalam berorganisasi dan menggerakkan modal sosialnya meskipun di tempat baru.

Lee juga menulis kepada Shih Sho He, bekas Konsul China di Kuala Lumpur yang juga berada di India untuk mendapatkan maklumat lanjut bagaimana cara untuk pulang ke China. ${ }^{19}$ Pada masa yang sama, Setiausaha Negara KMT, Jeneral Wu Te Chen ${ }^{20}$ yang pernah melawat ke Tanah Melayu pada tahun 1941 (sebagai Menteri Kementerian Luar Negara China pada masa itu) telah menghantarkan surat persendirian kepada Lee untuk menawarkan bantuan. Dengan perasaan terharu, Lee meminta bantuan $\mathrm{Wu}$ dari segi pengangkutan dan pertukaran asing untuk membawa ahli keluarganya balik ke China. ${ }^{21}$ Namun, apabila Lee menghubungi pegawai yang bertanggungjawab seperti yang dinyatakan oleh $\mathrm{Wu}$, Lee mendapati tiada pertimbangan istimewa bagi Lee dalam isu kadar pertukaran. Perkhidmatan penerbangan udara antara Calcutta dan Chungking pula dihentikan buat sementara waktu. Pada ketika yang sama, Yuen Koon Li (K.L. Yuen) selaku Pesuruhjaya Khas Hal Ehwal Orang Cina yang berundur dari Tanah Melayu, Hindia Timur Belanda dan negara-negara lain di India yang berasaskan di Calcutta juga menggalakkan Lee untuk pulang ke China secepat mungkin. ${ }^{22}$ Yuen menjamin bahawa semua susunan telah teratur di Chungking dan pelarian perang akan dijaga dengan baik. Beliau kemudiannya menawarkan diri untuk 'membantu' Lee bagi menukar wang dalam 'pasaran hitam' dan mendapat tiket kapal terbang dengan bayaran yang lebih tinggi.

Sebaliknya, Shih pula menasihatkan Lee untuk menetap di India kerana kadar inflasi yang tinggi di China di mana harga sebuku sabun Lux di Chungking adalah kira-kira 18 kali ganda lebih mahal daripada di India. ${ }^{23}$ Namun, selepas berjumpa dengan Yuen, Lee tetap memutus untuk menyewa dua buah kapal terbang untuk menghantar semua ahli keluarganya bersama ahli keluarga Chan Wing dan Chan Seng Chin ${ }^{24}$ yang berjumlah 60 orang. Namun, permintaan mereka ditolak atas alasan monsun dan kekurangan kapal terbang. ${ }^{25}$ Lee amat kecewa dan mengadu bahawa "perhatian khas" yang dijanjikan kepada pelarian perang Cina di luar negeri adalah janji kosong. Kerisauan tentera Jepun akan menyerang India masih menghantui Lee. Dalam surat kepada Wu, Lee menyatakan bahawa, "I have no alternative but to remain in India until the Japs drive me out again. If they do come, I presume that I would have to leave everything behind once again as I did in Singapore. This is, I am afraid, the plight of the Overseas Chinese." ${ }^{26}$

Yuen masih terus melobi untuk Lee dan akhirnya permohonan menyewa kapal terbang khas ke China telah diluluskan oleh Jeneral Wu Te Chen. ${ }^{27}$ Namun, Lee terpaksa menangguhkan rancangannya apabila beliau mengalami cedera parah yang teruk selepas terjatuh daripada kuda. ${ }^{28}$ Kecederaan ini meninggalkan parut yang nyata di muka Lee. Apabila pulang ke Tanah Melayu kemudian, ramai orang ingat parut ini adalah hasil penglibatan Lee dalam peperangan. Selepas pulih daripada kecederaan, Lee akhirnya bertolak dari Calcutta ke Chungking pada 23 Oktober 1942 seorang diri. ${ }^{29}$

Lee mendapat layanan yang buruk sebaik sahaja tiba di Chungking kerana Yuen yang sepatutnya menyambut beliau menghadiri latihan di tempat lain. ${ }^{30}$ Namun, walaupun mesyuarat Majlis Rakyat sedang diadakan, Lee masih dapat bertemu dengan Jeneral $\mathrm{Wu}$ Te Chen dan Shang Chen iaitu pengarah Jabatan Am Suruhanjaya Ketenteraan Pusat bersama ketua Biro Hal 
Ehwal Luar Suruhanjaya Ketenteraan Pusat yang Lee pernah berjumpa di Tanah Melayu semasa Shang mengetuai satu perwakilan tentera China melawat Tanah Melayu antara 4-17 Mei 1941. ${ }^{31}$

Paling penting ialah Lee dapat menghantar memorandumnya yang bertajuk "Persepsi Terhadap India dan Kedudukan Masa Depan Orang Cina di Tanah Melayu" kepada Jeneralisimo Chiang. ${ }^{32}$ Dalam memorandumnya, Lee meramalkan bahawa selepas perang, Tanah Melayu akan diberi status berkerajaan sendiri. Memandangkan lebih daripada separuh populasi Tanah Melayu adalah orang Cina, maka Lee dalam memorandumnya mencadangkan kepada Jeneralisimo untuk menubuhkan sebuah persatuan untuk menyatukan orang Cina yang berasal dari Tanah Melayu di Chungking (kira-kira lebih seratus orang) dan di India (lebih kurang tiga ratus orang). Sementara membangunkan industri dan perniagaan di China, persatuan ini kemudian boleh dijadikan asas untuk berurusan dengan pihak berkuasa tempatan. Jika ditambahkan lagi dengan sokongan kerajaan China, persatuan ini dapat bangkit dalam membantu memulihkan dan membina semula kepentingan orang Cina di Tanah Melayu selepas perang.

Selain pegawai tinggi kerajaan, Lee juga berjumpa dengan orang Cina yang melarikan diri dari Tanah Melayu dan menetap di Chungking. Ini termasuk Lau Pak Khuan ${ }^{33}$ dari Perak, Lien Ying Chow ${ }^{34}$ yang berasal dari Singapura dan Ho Poh Jin $^{35}$ dari Melaka. Selain berbincang tentang projek Overseas Chinese Union Bank yang bakal ditubuhkan di Chungking, ${ }^{36}$ Lee juga mencadangkan kepada mereka untuk membentuk sebuah persatuan orang Cina dari Tanah Melayu di Chungking tetapi mendapat sambutan yang dingin ${ }^{37}$ Namun, rangkaian yang dijanakan ini kemudian membawa Lee sebagai ahli lembaga pengarah Overseas Union Bank yang ditubuhkan oleh Lien Ying Chow di Singapura pada tahun 1949.

Dalam lawatan ini Lee mendapati bahawa kos sara hidup di Chungking adalah amat tinggi sekali dan masalah perumahan juga sangat serius. Lee menjangka kira-kira $\$ 50,000$ hingga $\$ 60,000$ diperlukan sebulan untuk menampung kehidupan keluarganya di Chungking. Chan Kwong Hon $^{38}$ yang berada di Chungking bersama keluarganya juga menasihati Lee untuk pergi ke Afrika Selatan atau Amerika daripada ke Chungking. Chan yang mengalami kesengsaraan dari segi kerohanian dan kebendaan berpendapat "overseas Chinese is only fit for overseas and not for home country". Chan ingin membawa keluarganya ke India semula tetapi terhalang kerana pihak kerajaan China tidak membenarkan emas berserta barangan kemas dibawa keluar dari China. ${ }^{39}$ Setelah mendengar pengalaman kawannya dan melihat dengan sendiri keadaan di China, Lee memutuskan untuk terus tinggal di India sehingga perang berakhir. ${ }^{40}$

\section{Penubuhan Persatuan Cina di India, 1943}

Lee kembali semula ke India pada awal bulan November $1942 .{ }^{41}$ Namun Lee tidak terlupa apa yang beliau cadangkan kepada Jeneralisimo iaitu penubuhan sebuah persatuan yang terdiri daripada orang Cina Tanah Melayu di India. Lee memberitahu kepada Yuen bahawa:

If I should get instructions from our [China] Government, I would not mind going round India to approach the rest of our Malayan Chinese to start something of the sort [Overseas Chinese organisation] here. There is already a Malayan Association here started by Europeans, and I think the Chinese will be worse off without a corresponding organisation. ${ }^{42}$ 
Lee kemudian menulis kepada Setiausaha Negara KMT iaitu Wu Te Chen dan menyatakan niatnya untuk mengembara di India bagi mendalami pemahaman terhadap keadaan serta situasi orang India dan orang Cina di sana. Lee juga ingin berjumpa dengan pemimpin Cina yang berasal dari Tanah Melayu yang tinggal di Bombay dan Bangalore untuk berbincang tentang isu pembinaan semula selepas peperangan berakhir, khasnya masalah politik, ekonomi dan sosial orang Cina seberang laut. Lee mengulangi bahawa orang Eropah telah membentuk Malayan Association of India (MAI), maka orang Cina harus tidak ketinggalan dalam menjaga kepentingan mereka dengan turut bersama menganjurkan persatuan yang serupa sifatnya. ${ }^{43}$

Bagi tujuan tersebut, Lee kemudiannya menulis kepada Wu Te Chen dan Shang Chen untuk meminta pelantikan jawatan dengan gelaran tertentu untuk memudahkan pergerakan beliau di India:

Touring in these days in India is a very difficult matter unless one has some sort of official title. Though I had the rank of Colonel in Kuala Lumpur when I was appointed the Chief Air Raid Warden with three thousand officers and men under me, I feel diffident in using it because I am a Chinese citizen and my previous appointment was British. I would therefore much prefer to have an appointment from our own [China] Government, carrying only a title simply for facilitating my travelling in this country. Should you feel inclined to make a recommendation for such an appointment, is would be very grateful. ${ }^{44}$

Shang Chen bersetuju dengan cadangan Lee, dan ingin melantik Lee sebagai penasihat kepada Biro Hal Ehwal Luar yang dilampirkan dengan pejabat yang baru dibuka di Ramgarh, India. ${ }^{45}$ Namun, Lee merasakan jawatan pangkat tentera yang berpakaian seragam adalah lebih sesuai.

The proposed appointment will suit me admirably if I were given a military rank, thus enabling me travel in uniform which will greatly facilitate touring in time of war. It will endeavour to tender my advice on foreign affairs when such matters could be perceived within my very limited ability. ${ }^{46}$

Oleh itu, Lee dilantik sebagai atase yang mana pangkatnya setara dengan kolonel. ${ }^{47}$ Pelantikan ini membolehkan Lee menggunakan gelaran kolonel dan Penasihat di Pejabat Ramgarh Biro Hal Ehwal Luar Negeri, Ramgarh, India pada kad namanya. Jeneral Wu pula melantik Lee sebagai Canselor Majlis Hal Ehwal Orang Cina Seberang Laut. ${ }^{48}$

Yuen juga menyampaikan hasrat Lee untuk memulakan Persatuan Orang Cina Tanah Melayu di India kepada Wu dan mendapat sambutan yang baik. Nama South Seas Chinese Association Malayan Branch telah disyorkan dengan South Seas Chinese Association ${ }^{49} \mathrm{di}$ Chungking sebagai badan induk. ${ }^{50}$ Walau bagaimanapun, sebelum Lee mengambil apa-apa tindakan, Tan Cheng Lock ${ }^{51}$ yang berasal dari Melaka di Bangalore telah memulakan rancangannya untuk menubuhkan Overseas Chinese Organisation (OCA) yang ahlinya merangkumi semua orang Cina di India termasuk orang Cina dari Tanah Melayu. Sebenarnya 
idea penubuhan OCA India ini bukan datang daripada Tan Cheng Lock tetapi Walter Fletcher iaitu seorang peniaga getah yang bekerja dengan Anglo-French Co di Tanah Melayu sebelum perang. ${ }^{52}$ Semasa pendudukan Jepun di Tanah Melayu, Fletcher melarikan diri ke India dan bekerja di bawah Special Operations Executive (SOE) bagi kerajaan British. ${ }^{53}$ Ini disahkan oleh nota yang disediakan oleh pegawai Tanah Jajahan British, G. E. J. Gent selepas berjumpa dengan Fletcher:

\begin{abstract}
He [Fletcher] had promoted the establishment in India an Overseas Chinese Association (virtually and deliberately so a Chinese-Malayan Association) under the presidency of Tan Cheng Lock. He did this as something of a counter to direct Chungking claims to be the only source from which responsible Chinese interests in Malaya could properly be expressed. ${ }^{54}$
\end{abstract}

Lee diajak oleh Tan Cheng Lock dan anaknya, Tan Siew Sin ${ }^{55}$ sebagai penaja dan ahli jawatankuasa OCA India. ${ }^{56}$ Nama Lee disyorkan oleh Tsiang iaitu merupakan Konsul China di Bombay kepada Tan Cheng Lock dan anaknya kerana:

You are a man of great ability and considerable experience of public life in Malaya, where you are well-known and where you have had a good deal of influence....you are also well-known amongst the Chinese officials both here and Chungking... ${ }^{57}$

Seperti yang dikatakan oleh Tan Siew Sin, selain Tan Cheng Lock, Lee adalah satu-satunya orang Tanah Melayu yang berpengalaman dalam perkhidmatan awam di India. Walaupun tidak pernah berjumpa sebelum ini, Lee pasti pernah mendengar nama Tan Cheng Lock atau membaca kisahnya di surat khabar. Tan Cheng Lock merupakan satu-satu wakil Cina dalam ahli Majlis Eksekutif Negeri-negeri Selat (1933-1935) yang berkhidmat sebagai ahli Majlis Perundangan Negeri-negeri Selat selama 12 tahun (1923-1934) dan mengundur kan diri daripada politik selepas tahun 1936.

Selain H.S. Lee dan Tan Cheng Lock, terdapat satu lagi kumpulan pelarian perang yang berasal dari Tanah Melayu di India pada masa itu. Mereka telah membentuk Malayan Association of India (MAI) dan ahlinya terdiri daripada orang Eropah, orang Yahudi dari Singapura, kerabat diraja Melayu dan orang Cina peranakan pada Disember $1942 .{ }^{58}$ Pertikaian wujud dalam kalangan ahli persatuan dan menyebabkan berlakunya perpecahan kepada dua kumpulan utama. Satu kumpulan diketuai oleh John Laycock ${ }^{59}$ dan Tengku Abu Bakar iaitu anak Sultan Johor. Manakala kumpulan satu lagi diketuai oleh Joseph Aaron Elias ${ }^{60}$ dan Herbert E. Fancott. ${ }^{61}$ Dikatakan apabila perselisihan tidak dapat diselesaikan, orang Cina di bawah pimpinan Tan Cheng Lock telah meninggalkan persatuan ini dan membentuk OCA India. ${ }^{62}$

Lee gagal melihat keberkesanan OCA India. Beliau berpendapat badan ini adalah 'unwieldy and impracticable' kerana meliputi kawasan wilayah yang terlalu luas dan sekumpulan orang yang mempunyai kepentingan yang berbeza. ${ }^{63}$ Berbeza dengan pelarian perang Cina dari Tanah Melayu yang kebanyakan adalah golongan berada yang berpendidikan Inggeris, tetapi orang Cina di India kebanyakan berpendidikan rendah dan terlibat dalam sektor 
pembuatan. ${ }^{64}$ Dengan menggunakan orang Cina di Calcutta sebagai contoh, Lee mendapati walaupun terdapat banyak persatuan Cina berasaskan suku kaum (clan association) dan daerah asalan (district guild) tetapi masih tidak terdapat satu badan pusat malahan satu dewan perniagaan, walaupun mereka sudah lama tinggal di Calcutta. ${ }^{65}$ Lee berpendapat adalah sukar bagi OCA India untuk menyatukan orang Cina yang berasal dari provinsi yang berbeza di China, bertutur dalam dialek masing-masing dan mengamalkan tradisi yang pelbagai. Oleh demikian, daripada menerima jemputan daripada Tan Cheng Lock dan Tan Siew Sin, Lee sebaliknya mempelawa mereka untuk bersama-sama membentuk sebuah persatuan orang Cina Tanah Melayu di bawah South Seas Chinese Association di Chungking. ${ }^{66}$ Pada pendapat Lee, keperluan mendapatkan sokongan daripada kerajaan China adalah satu kemestian. "After all what could an oversea-Chinese organisation hope to achieve for its members if it were not supported by their own [China] Government?". ${ }^{67}$ Namun, bagi Tan Cheng Lock, South Seas Chinese Association adalah badan yang dikawal oleh kerajaan. ${ }^{68}$ Jenis persatuan yang Lee ingin tubuhkan adalah:

It is but an organisation the members of which propose now to discuss and to prepare plans for the future after victory is won. The major portion of the work will be in Malaya, the recruitment of members, the consultation with those leaders now confined there, and above all the consideration of the actual condition that will be prevailing in the country. ${ }^{69}$

Walau bagaimanapun, cadangan Lee tidak diterima oleh Tan Cheng Lock dan anaknya. Rancangan diteruskan dengan mengadakan mesyuarat penubuhan OCA India di K. R. Cama Oriental Institute, Bombay pada 24 September 1943 dan mesyuarat Agung pertama untuk melantik ahli jawatankuasa pada tiga hari kemudian. ${ }^{70}$ Tan Cheng Lock telah dipilih sebagai presiden pertama dan anaknya, Tan Siew Sin dilantik sebagai setiausaha dan bendahari. ${ }^{71}$ Antara aktiviti yang pernah dijalankan oleh OCA India adalah menyenaraikan Daftar Kelayakan (Qualifications Register) ahlinya untuk kegunaan Negara-negara Bangsa Bersekutu dan pencarian pekerjaan, menyusun tuntutan bagi pihak ahlinya ke atas kehilangan harta benda atau barangan akibat pendudukan Jepun dan mengumpul kisah tentang sumbangan orang Cina seberang laut dalam menentang pendudukan Jepun. ${ }^{72}$

Walaupun persatuan ini dikatakan telah mendapat sokongan daripada hampir semua orang Cina yang berasal dari Tanah Melayu dan orang Cina dari seberang laut yang berada di Bombay, Calcutta, Madras, Bangalore dan Delhi pada peringkat permulaan, ${ }^{73}$ namun kritikankritikan telah timbul selepas OCA India ditubuhkan. Antaranya adalah ahli jawatankuasa yang dibentuk kebanyakannya berasal dari Tanah Melayu. Oleh itu, orang Cina yang berasal dari tempat lain teragak-agak untuk menyertainya kerana penubuhan persatuan ini diinspirasikan oleh pihak British maka disyaki ia direka untuk kepentingan British dan apa yang terpenting ialah penubuhan OCA India yang akan merampas fungsi Konsul China. ${ }^{74}$ Konsul Jeneral China di India, Dr C. J. Pao mengadu dengan Tan Chin Tuan ${ }^{75}$ iaitu timbalan presiden OCA India, bahawa tiada maklumat lanjut diberikan oleh Tan Siew Sin selepas perjumpaan pertama dengannya dan persatuan ini telah ditubuhkan dengan serta-merta di Bombay. ${ }^{76}$ OCA India yang tidak berdaftar dengan pihak kerajaan China seolah-olah mendapat sokongan penuh daripada pihak kerajaan British walaupun Konsul Pao menawarkan diri untuk memberi bantuan. Dengan perasaan bahawa pihak kerajaan China telah diabaikan, Konsul Pao mengarahkan orang Cina di 
India menarik diri dari OCA India. ${ }^{77}$ Orang Cina dari Burma juga tidak berpuas hati kerana Tan Siew Sin telah memberikan kredit terhadap penubuhan OCA India kepada orang Cina di Tanah Melayu. ${ }^{78}$ Orang Melayu di India pula merasai tidak selesa dengan tindakan OCA India untuk campur tangan dalam hal ehwal dalam Tanah Melayu kerana ahlinya bukan hanya terhad kepada orang Cina dari Tanah Melayu sahaja. ${ }^{79}$

Sementara itu, selepas dilantik sebagai Penasihat Majlis Hal Ehwal Orang Cina Luar Negara oleh kerajaan China, Lee merancang untuk berjalan di sekitar India dengan perbelanjaan sendiri untuk berbincang tentang penubuhan persatuan orang Cina Tanah Melayu. ${ }^{80}$ Namun, rancangan Lee terpaksa ditangguhkan, sebahagian besar mungkin disebabkan oleh penubuhan OCA India oleh Tan Cheng Lock dan kewujudan MAI. Tambahan pula, selepas menerima surat pelantikan rasmi dan pas ketenteraan, Lee diminta untuk melaporkan diri dengan Jeneral Yeh Nan di Ramgarh. Walau bagaimanapun, Lee tidak diberikan apa-apa tugas selepas bertemu dengan Jeneral Yeh. ${ }^{81}$ Lee lalu menulis kepada Shang Chen dan bercadang untuk berkhidmat dengan Biro Hal Ehwal Luar Negeri berkenaan dengan kerja-kerja hubungan dengan kuasa British dan Amerika di Bombay tetapi ditolak dengan alasan kakitangan yang sedia ada sudah mencukupi. ${ }^{82}$ Sebaliknya Lee ditawarkan untuk berkhidmat dengan Chinese Foreign Relations Association (Persatuan Perhubungan Luar China) iaitu di bawah Jeneral $\mathrm{Wu}$ Te Chen untuk mempromosikan negara China. ${ }^{83}$ Lee dikatakan "living swell" dan rumahnya di Bombay menjadi tumpuan aktiviti sosial yang diziarahi oleh orang ternama. ${ }^{84}$

Beberapa tahun kemudian, dalam satu wawancara, Lee mengatakan bahawa beliau pernah menerima latihan ketenteraan selama enam bulan yang dikendalikan oleh pegawai Amerika di Ramgarh, sebelum berkhidmat di bawah Jeneral Joseph Stilwell, kemudian Jeneral William Slim di Burma. ${ }^{85}$ Kemudian, beliau kembali semula ke India sebagai pegawai perhubungan (liaison officer). Namun dalam kertas persendirian Lee, tidak terjumpa rekod yang berkaitan dengan pengalaman jangka masa ini. Ia mungkin disebabkan oleh misi yang Lee jalankan adalah terlalu sensitif untuk dicatat atau disimpan atau Lee sebenarnya tidak terlibat dalam kerja peperangan yang sebenar. ${ }^{86}$

\section{Komuniti Tanah Melayu di India, 1944-1945}

Pada mulanya, para pelarian perang berpendapat bahawa perang ini akan berakhir tidak lama lagi. Oleh itu, masing-masing menganggap India sebagai tempat persinggahan sementara untuk pulang ke tempat masing-masing. Apabila peperangan semakin berlarutan, India pula menjadi batu loncatan untuk pergi ke China, koloni-koloni British yang lain atau negara Barat terutamanya Amerika. Namun bukan semua orang berupaya pergi ke tempat lain dan hampir semua negara di dunia terlibat dalam perang ini, sama ada secara langsung atau tidak langsung. Apabila peperangan dilanjutkan dari bulan kepada tahun, mereka yang berada di India mulai mencari kerja, sama ada untuk menampung kehidupan atau semata-mata untuk mengisi masa lapang. ${ }^{87}$ Kebanyakan daripada mereka adalah peniaga, walaupun bukan daripada golongan profesional tetapi berpendidikan Inggeris. Maka, masih dapat diterap oleh agensi kerajaan British yang memerlukan tenaga pekerja semasa perang. Misalnya, Chan Kwong Hon iaitu kawan baik Lee yang berpindah dari China ke India dan telah bekerja dengan All India Radio sebagai penterjemah dan juruhebah dalam bahasa Kantonis. ${ }^{88}$ Chan Hin Cheung, anak kepada Chan Wing juga bekerja dengan All India Radio, ${ }^{89}$ Lao Yusan $^{90}$ dan Loke Tai Wah ${ }^{91}$ pula menyertai S.O.S. Engineering. Gaji permulaan yang ditawarkan adalah antara Rs 250 -Rs 300, sama dengan kadar sewa untuk rumah Lee di Bombay (Rs 300 sebulan). Sesetengah daripada mereka pula memulakan perniagaan sendiri. Misalnya, Foo Meow Chin, menantu lelaki Choo Kia Peng 
terlibat dalam perniagaan menyamak kulit binatang di Madras dan Ong Peng Hock, pemilik New World Park di Singapura, memulakan kabaret baru di Bangalore. ${ }^{92}$ Secara amnya, kebanyakan wanita terlibat dalam kerja kesetiausahaan, kejururawatan, pendidikan dan kebajikan sosial. ${ }^{93}$

Sepanjang empat tahun di India, ahli keluarga Lee yang lain hanya bergantung kepada wang simpanannya di Chartered Bank dan Bank of China untuk menampung kehidupan. ${ }^{94}$ Dengan wang simpanan ini, Lee masih boleh mengekalkan kehidupan yang agak selesa. Ini dapat diteliti apabila beliau mula-mulanya tiba di Calcutta, beliau dan keluarganya berupaya tinggal di Great Eastern Hotel iaitu salah satu hotel yang paling mewah pada masa itu. ${ }^{95}$ Beliau juga mampu mengupah empat pembantu rumah semasa berada di Mussoorie, membeli kereta apabila berada di Bombay ${ }^{96}$ dan menunjukkan minat yang tinggi apabila diberitahu tentang projek perbankan di Chungking. ${ }^{97}$ Selain Lee, ramai pelarian perang dari Tanah Melayu juga amat kaya. Apabila Lau Pak Khuan ingin mencari pelabur untuk projek perbankan di Chungking, bekas konsul China di Tanah Melayu iaitu Shih menyatakan bahawa adalah tidak sukar untuk mengumpul 500,000 rupee yang diperlukan kerana "there are many others from Malaya, who do not know what to do with their money". 98

Semasa berada di India, pendidikan anak-anak Lee juga tidak diabaikan. Tempat yang Lee tinggal di Mussoorie merupakan pusat pendidikan yang agak terkenal dan pelajarnya terdiri daripada kanak-kanak yang datang dari seluruh India. ${ }^{99}$ Oleh itu, anak sulungnya, Douglas telah menyambungkan pelajarannya di Woodstock High School, ${ }^{100}$ Cecil dan Violet belajar di Wynberg Girls' High School ${ }^{101}$ manakala George dan Robert pula belajar di Allen Memorial Boys' High School. ${ }^{102}$ Apabila Lee jemu dengan perpindahan yang perlu dilakukan pada setiap musim sejuk di Mussoorie, Lee teragak-agak sama ada hendak berpindah ke Karachi atau Bombay. Kualiti pendidikan yang ditawarkan di Bombay menjadi salah satu sebab ia dipilih walaupun kos hidupnya lebih tinggi. ${ }^{103}$ Douglas telah melanjutkan pelajarannya ke Elphinstone College, Universiti Bombay ${ }^{104}$ manakala anak-anaknya yang lain masuk ke Cathedral \& John Connon High Schools di Bombay yang mengandungi Cathedral Boys' School, Cathedral Girls' School, dan John Connon School.

Bilangan penduduk Tanah Melayu yang tinggal di Bombay adalah agak ramai. Mereka sering bertemu antara satu sama lain. Douglas, anak sulung Lee, teringat "our only form of entertainment was the tea dances organised at the Taj Mahal Hotel in Bombay. It was [an] oncea-month affair and Malayan refugees would meet there." ${ }^{105} \mathrm{Di}$ sanalah, Douglas terjumpa dengan Ruby Ong Chian Kim, bakal isterinya. ${ }^{106}$ Manakala bagi Lee, beliau berupaya menyambung semula hobinya bermain golf di Bombay kerana padang golf hanya beberapa batu jauh dari tempat tinggalnya. Padang golf yang Lee selalu pergi mungkin adalah Kelab Sukan Wellingdon yang ditubuhkan pada 1918 dan merupakan kelab pertama yang menerima orang India sebagai ahlinya. Di sana, Lee dapat bergaul dengan golongan pihak atasan India, malahan Maharaja Pratap Sinh dari negeri Baroda juga menjemput Lee untuk menyertai dalam pertandingan golf yang diadakan di Baroda sempena hari jadinya. ${ }^{107}$

Sambil sibuk dengan aktiviti sosial harian, Lee juga mengikuti perkembangan terkini peperangan melalui radio dan akhbar setiap hari. Namun, berita yang dapat diterima adalah amat terhad, terutamanya tentang situasi di Tanah Melayu. Oleh itu, jaringan rangkaian antara para pelarian perang yang berasal dari Tanah Melayu menjadi amat penting. Chan Kwong Hon yang bekerja di All India Radio merupakan salah satu sumber maklumat Lee. Chan telah memperkenalkan Hsu Chen Shung, pengurus Bank of China yang meninggalkan Kuala Lumpur pada bulan Oktober 1943 kepada Lee dan didapati Kam Lun Tai masih meneruskan perniagaannya di Kuala Lumpur. ${ }^{108}$ 
Sebenarnya adik perempuan Lee, Pearl Lee Yue Wai dan bapa saudaranya, Lee Man Sau masih berada di Tanah Melayu semasa pendudukan Jepun. ${ }^{109}$ Maka segala perniagaan keluarga Lee di Tanah Melayu masih beroperasi dibawah pengurusan Yue Wai. Ini termasuk Tai Yau Tin Mines, rumah tumpangan Kam Lun Tai, You Tai Timber Kongsi di Cheras dan kilang batu kapur di Batu Cave. Malahan, atas arahan pihak Jepun, lombong timah baru telah dibuka. ${ }^{110}$ Akaun-akaun yang disimpan menunjukkan pelanggan utama adalah tentera laut Jepun dan makanan seperti beras diterima sebagai bayaran. Namun bekalan yang diterima adalah tidak mencukupi. Untuk menyara kira-kira 40-50 pekerja di bawahnya, Yue Wai juga bekerja sebagai penterjemah bagi tentera laut Jepun bagi mendapatkan bekalan makanan tambahan selain keledek dan ubi kayu. ${ }^{111}$ Oleh sebab hubungannya yang rapat dengan pihak Jepun, Yue Wai dikatakan telah dibunuh oleh pihak anti Jepun selepas Jepun menyerahkan kalah pada akhir tahun 1945. Manakala adik bongsunya, Lee Hau Wai pula berada di kampung halamannya di Xinyi, Kwangtung, China. ${ }^{112}$

Sejak keinginan untuk menubuhkan sebuah persatuan orang Cina Tanah Melayu telah didahului dengan penubuhan OCA India oleh Tan Cheng Lock dan tidak banyak yang boleh Lee lakukan melalui kerajaan China di India kerana jawatan yang dipegang adalah terhad dan hanya pada nama, bukan dalam konteks sebenar. Maka Lee mengubah hala tujunya dengan bekerjasama dengan pihak British. Oleh sebab peranan yang dimainkan oleh Lee dalam industri perlombongan, Lee telah dihubungi untuk memberi nasihat dalam pemulihan industri perlombongan timah oleh Malayan Planning Unit (Unit Perancangan Tanah Melayu) di India pada tahun 1944. ${ }^{113}$ Rakan sekelas Lee di Cambridge, Victor Purcell, ${ }^{114}$ yang sebelumnya adalah Chinese Protectorate di Selangor dan Pahang merupakan salah seorang perancang utama unit ini. ${ }^{115}$ Lee telah berhubung dengan pengusaha lombong timah Tanah Melayu di India pada masa itu untuk mengumpul pendapat mereka tentang langkah-langkah pemulihan industri timah selepas perang. Hasil daripada itu, sebuah memorandum telah dirangka oleh Lee untuk dihantar ke London. ${ }^{116}$

Lee juga menyertai Malayan Association of India (MAI) yang bekerja rapat dengan pihak British dan dilantik sebagai salah seorang ahli jawatankuasa untuk sesi 1944/45 di mana Tan Chin Tuan adalah presidennya. ${ }^{117}$ Kejatuhan bom atom di Hiroshima dan Nagasaki telah mengakhiri Perang Dunia Kedua secara rasmi. Pada 3 September 1945, British menduduki semula Tanah Melayu. Para pelarian perang di India amat gembira dengan berita ini dan masingmasing menunggu untuk pulang semula ke kampung halaman di Tanah Melayu. Sebagai ahli MAI, Lee dan Tan Chin Tuan telah dihubungi oleh wakil Pejabat Tanah Jajahan di India untuk menyenaraikan senarai keutamaan orang Cina yang akan dihantar balik ke Tanah Melayu. ${ }^{118}$ Dengan pengalaman lalu dalam industri timah, Lee dilantik ke dalam Tin Inspection Committee (Tanah Melayu) yang berada di bawah Civilian Office, British Military Administration (BMA) di Bombay oleh Pejabat Tanah Jajahan British. Lee adalah antara kumpulan pertama 'sponsored civilians' yang dihantar kembali ke Tanah Melayu pada bulan Oktober 1945 untuk mengkaji keadaan industri bijih timah di Tanah Melayu selepas pendudukan Jepun. ${ }^{119}$ Antara pemimpin Cina dalam senarai keutamaan untuk kembali ke Tanah Melayu termasuklah Tan Chin Tuan untuk memulihkan semula operasi OCBC bank ${ }^{120}$ dan Tan Siew Sin sebagai Adviser for Chinese Affairs (Penasihat kepada Hal Ehwal Cina). ${ }^{121}$ Manakala Tan Cheng Lock hanya pulang ke Tanah Melayu pada bulan Jun 1946. ${ }^{122}$ 


\section{Kepulangan Lee ke Tanah Melayu}

Kepulangan Lee telah menerima sambutan yang hangat daripada penduduk Cina di Selangor. Sebuah majlis penyambutan khas telah diadakan oleh Selangor Chinese Assembly Hall (SCAH) untuk meraikan kepulangan Lee pada 24 November $1945 .{ }^{123}$ Kira-kira 200 orang terdiri daripada wakil-wakil daripada Malayan Peoples' Anti-Japanese Army (MPAJA), Parti Komunis Malaya (PKM), Kuomintang (KMT) dan 107 buah persatuan-persatuan Cina di Selangor telah menghadiri majlis ini. Dalam ucapannya, Lee memberitahu mereka yang hadir bahawa beliau telah pergi ke Chungking atas panggilan Jeneralisimo Chiang. Oleh sebab tidak berminat dengan politik, beliau memohon untuk menyertai ekspedisi di India yang menyediakan peluang untuk membunuh musuh dan membalas dendam. Selepas menerima latihan tentera di Ramgarh, beliau berkhidmat di India dan bahagian utara Burma lalu mendapat gelaran kolonel sebelum dihantar ke Bombay pada tahun 1944. Pada masa yang sama, Lee juga dijemput oleh kerajaan British untuk menyertai pasukan tenteranya tetapi beliau menolak dan hanya menerima tawaran sebagai penyiasat industri timah. ${ }^{124}$ Ini ditambah dengan parut di bahagian muka akibat kesan jatuh daripada menunggang kuda yang mengukuhkan lagi imej wira peperangan Lee. Beliau seolaholah sengaja mereka imejnya sebagai pahlawan bagi menyembunyikan hakikat sebenar bahawa beliau telah melarikan diri dari Tanah Melayu semasa pendudukan Jepun.

Percubaan Lee untuk menokok tambah pengalamannya di India tidak boleh disalahkan memandangkan keadaan huru-hara selepas pendudukan semula British di Tanah Melayu. British yang gagal mempertahankan Tanah Melayu semasa pendudukan Jepun juga cuba menonjolkan imej sebagai pelindung Tanah Melayu dengan menghebohkan jasa Force 136 yang dibentuk oleh British di India dan pengorbanan Lim Bo Seng dengan mengangkat beliau sebagai wira perang. ${ }^{125}$ Perang Dunia Kedua telah membawa impak yang besar terhadap struktur kuasa dan sistem kepimpinan masyarakat Cina di Tanah Melayu. Pada akhir perang, gerakan komunis muncul sebagai kuasa politik yang paling dominan bukan sahaja dalam masyarakat Cina tetapi juga di dalam negara. Para pemimpin yang aktif dalam gerakan anti Jepun sebelum perang yang masih tinggal di Tanah Melayu, sama ada telah dibunuh atau terpaksa bekerjasama dengan tentera Jepun. ${ }^{126}$ Dianggarkan kira-kira 40,000 orang terbunuh dalam sook ching iaitu satu pembunuhan secara sistematik dan besar-besaran terhadap orang Cina ${ }^{127}$ Kesannya, ramai pemuda Cina melarikan diri ke dalam hutan dan sesetengahnya telah menyertai gerakan anti Jepun bawah tanah.

Pemimpin-pemimpin persatuan Cina yang terlepas daripada sook ching pula terpaksa bekerjasama dengan Jepun melalui Oversea Chinese Association (OCA) yang ditubuhkan di setiap negeri untuk mengganti persatuan-persatuan Cina yang sedia ada. Pihak Jepun telah melantik pemimpin daripada kumpulan dialek masing-masing untuk menjalani dasar OCA, terutamanya kutipan wang sebanyak $\$ 50$ juta sebagai 'hadiah' daripada masyarakat Cina sebagai 'pampasan' untuk pihak ketenteraan Jepun atas penglibatan orang Cina dalam gerakan anti Jepun sebelum perang. ${ }^{128}$ Kerjasama pemimpin-pemimpin ini dengan pihak Jepun telah mencemarkan nama baik mereka sendiri dan menyebabkan mereka kehilangan sokongan dan penghormatan daripada penduduk Cina. Malah sesetengah daripada mereka yang dianggap sebagai pengkhianat, misalnya Wong Tet San, Presiden OCA Selangor telah dibunuh oleh MPAJA pada 15 Januari 1945. ${ }^{129}$ Sementara itu, terdapat pemimpin OCA yang dapat menyambung semula sebagai pemimpin masyarakat Cina selepas perang kerana bekerjasama dengan MPAJA secara rahsia semasa pendudukan Jepun, misalnya Heah Joo Seang dan Ng Teong Kiat. ${ }^{130}$

KMT Tanah Melayu pula hilang daripada mata masyarakat kecuali segelintir daripada ahlinya yang masuk ke hutan dan membentuk Overseas Chinese Anti-Japanese Army (OCAJA). 
OCAJA dikatakan sebagai angkatan yang kurang berdisiplin dan hanya mengandungi kira-kira 400 orang jika dibandingkan dengan 7,000 anggota daripada MPAJA yang ditubuhkan oleh komunis. Selepas penyerahan Jepun tetapi sebelum pentadbiran ketenteraan British iaitu British Military Administration (BMA) diadakan, wujud satu ruang kekosongan politik di mana pihak komunis telah mengambil alih pentadbiran di banyak tempat. ${ }^{131}$ Manakala mereka yang melarikan diri dari Tanah Melayu pula dianggap sebagai penakut. Maka, Lee yang baru pulang dengan gelaran kolonel terpaksa menokok tambah pengalamannya di India dan mengizinkan cerita rekaan ini disebar bagi mengelakkan diri daripada dipersalahkan. Tindakan ini telah menjadikan Lee muncul semula sebagai pemimpin masyarakat Cina golongan konservatif, malah pengaruhnya menjadi lebih besar jika dibandingkan dengan sebelum perang.

\section{Kesimpulan}

Perang Dunia Kedua merupakan titik perubahan dalam hidup H.S. Lee. Beliau amat kecewa dengan pihak British yang selama ini selaku pelindung Tanah Melayu telah ditewaskan oleh tentera Jepun dalam masa yang singkat. Ini ditambah dengan pengalamannya yang pahit semasa melarikan diri dari Singapura dan pengabaian yang dialami oleh beliau semasa berada di India. Manakala bagi pihak China, walaupun pegawai China telah menghulurkan bantuan semasa Lee meninggalkan Singapura dan tiba di India, Lee masih memilih untuk menetap di India sepanjang pendudukan Jepun selepas beliau melawat dengan sendirinya ke China. Lee mendapati adalah amat sukar bagi orang Cina seberang laut yang sudah biasa dengan kehidupan di luar negara untuk menetap semula di China. Beliau juga sedar bahawa kerajaan China yang diharapkan tidak berupaya memberi sebarang bantuan yang sebenar apabila diperlukan. Semasa berada di India, Lee telah menyaksikan kempen "Quit India" yang dilancarkan untuk mendapat kemerdekaan daripada pihak British. Kesemua di atas mungkin tidak memberi kesan terhadap Lee dengan serta-merta, tetapi kemudian mempengaruhi keputusan beliau untuk mendapat kemerdekaan bagi Tanah Melayu.

Buat pertama sekali, Lee mempunyai hubungan langsung dengan Tan Cheng Lock dan Tan Siew Sin yang selama ini berada di Tanah Melayu tetapi tidak bergaul antara satu sama lain untuk membincangkan masa depan orang Cina di Tanah Melayu. Walaupun Lee tidak menyertai OCA yang ditubuhkan oleh Tan Cheng Lock, tetapi kenalan dengan Tan ini membawa kepada penubuhan Malayan Chinese Association (MCA) kemudian. Lee juga membina hubungan persahabatan dengan pelarian perang Tanah Melayu yang lain terutamanya Chan Kwong Hon yang kemudian menjadi penyokong utama dalam aktiviti politik awal Lee di Tanah Melayu.

Lee Hau Shik selaku anggota ahli Jawatankuasa Pemeriksaan Timah yang dihantar kembali ke Tanah Melayu oleh pihak British telah dianggap sebagai pembebas Tanah Melayu daripada cengkaman sengsara pendudukan Jepun. Ditambah lagi dengan pangkat kolonel, uniform tentera Cina dan parut di muka, Lee telah diangkat sebagai wira perang bukan sahaja dalam kalangan masyarakat Cina Selangor tetapi di peringkat kebangsaan. Maka dalam masa yang singkat Lee berupaya berbangkit semula sebagai pemimpin masyarakat Cina dan menyatukan masyarakat Cina ke arah kemerdekaan. 


\section{Nota}

${ }^{1}$ Lee dikenali sebagai subjek British kerana beliau dilahirkan di Hong Kong, sebuah koloni British. Dalam rayuan ke mahkamah Kuala Lumpur terhadap hartanah bapanya yang meninggal dunia, Folio HSL. 9.34., Lee menyatakan "I, Hau Shik Lee, of full age, of British subject... ."

${ }^{2}$ Xinyi Xian Difangzhi BianzuanWeiyuanhui (eds.), Xinyi Renwu Luezhuan (Biografi Ringkas Orang Ternama Xinyi), Guangdong: Zhongshan Daxue Chubanshe, 1990, hlm. 53-54.

${ }^{3}$ Yang Yong Tai (1880-1936) pernah berkhidmat sebagai Menteri Kewangan Guangdong, Gabenor Provinsi Guangdong, ahli Dewan Negara, ahli Senat Kerajaan di Nanjing, Ketua Setiausaha Suruhanjaya Ketenteraan Pusat, Setiausaha Serangan Penyamun Provinsi Henan, Hubei dan Anhui, dan Gabenor Provinsi Hubei. Sila rujuk Zhuo Yu He, 'Yang Yong Tai: Chiang Kai Shek Shen Bian de Zhugeliang (Yang Yong Tai: Penasihat di Tepi Chiang Kai Shek)', Tong Zhou Gong Jin, Jil. 4, 2009, diakses http://jds.cass.cn/UploadFiles/ztsjk/2010/11/201011240932396716.pdf, tarikh capaian: 23 Mei 2013. Yang Yong Tai berkahwin dengan Lee Wu Zhen iaitu adik perempuan kepada K.L. Lee. Sila rujuk Lee Hau Shik, 23/05/1950 22/06/1950, Arkib Taiwan 002-080101-00018-001.

4 Fujio Hara, 'An Alternative View of Tun Sir H. S. Lee: The Anti-Japanese Movement and His Dedication to China', Journal of Asia-Pacific Studies, No. 20, 2013, hlm. 53-63.

${ }^{5}$ The Straits Times, 7 Sep. 1939; dan lihat juga The Union Times, 14 Sep. 1939.

${ }^{6}$ The Straits Times, 11 Nov. 1940 dan Letter from H.S. Lee to the officer in charge of Central Record Office, Volunteer Forces Record Office, 26 September 1946, Malayan Union no. 10073/1946, Arkib Negara Malaysia.

${ }^{7}$ Sun Bi Qi, 'Chang Hai Fu Sheng Ji (Catatan kehidupan yang singkat),' Zhuan Ji Wen Xue, Jil. 22, No. 2, 1973, hlm. 6-9.

8 Ng Poh Tip, 'The Amazing Tun Sir Henry H. S. Lee', Malaysian Business, Julai 1980, hlm. 88-97. Namun mengikut kajian Fujio Hara, beliau belum terjumpa apa-apa dokumen Jepun yang menyatakan S\$60,000 ditawarkan untuk mendapat kepala Lee. Sila rujuk Hara Fujio, 'An Alternative View of Tun Sir H. S. Lee: The Anti-Japanese Movement and His Dedication to China', hlm. 58.

${ }^{9}$ Kenyataan yang dikeluarkan oleh O.H. Farrar, Ketua Kapal S.S. Haiching (kepunyaan Douglas Steamship Company) di pelabuhan pada 12 Februari 1942, Folio HSL 14.1/4. Kesemua penumpang (107 orang) adalah orang Cina dan tiga per empat daripada mereka adalah golongan wanita dan kanak-kanak.

${ }^{10}$ Ahli keluarga Lee bertolak ke India pada 28 Januari 1942. Adiknya, Lee Hau Mo dan anak sulungnya, Douglas Lee pula bersama dengan Lee dalam pelayaran ini. Sila rujuk Surat daripada H.S. Lee kepada Jin Hai, 22 April 1943, Folio HSL 121.

${ }^{11}$ Perenggan seterusnya adalah berasaskan temu bual oleh $\mathrm{Ng}$ Poh Tip, 'The Amazing Tun Sir Henry H. S. Lee'. Surat yang ditulis oleh Lee kepada Jin Hai , 22 April 1943, Folio HSL 121 dan Surat kepada J. Martin Bell, 27 April 1942, Folio HSL 121.

${ }^{12}$ Pejabat Koloni menganggar terdapat kira-kira setengah juta pelarian perang dari pelbagai tempat di dunia berlari ke India (Memorandum, CO825/33/9(9)). Kemtekar pula menganggar Calcutta sahaja telah menerima hampir 405,000 pelarian perang (Indivar Kamtekar, 'The Shiver of 1942', Studies in History, Jil. 18, No. 1, 2002, hlm. 84, nota 18) ; manakala mengikut Zhang Xiu Ming, 'A Marginalized Community: The Changes and Development of the Chinese Community in India', Overseas Chinese History Studies, No. 4, 2008., orang Cina seberang laut di India telah meningkat daripada 14,000 orang (tahun 1936) kepada 27,000 orang pada tahun 1941 akibat daripada kemasukan pelarian Cina dari Asia Tenggara.

${ }^{13}$ Relief of Malayan Evacuees in India, CO 825/33/9 (9). Kem pelarian juga berselerak di seluruh India -Nainital, Bareilly, Rajkot, Mout Aku, Coldetatore, Octacamurdard dan lain-lain, (Malayan Association Overseas: minutes of meeting held at Martin Place, Sydney, 11 Nov 1942; constitution and rules, CO825/35B/11 (55-56). Namun dikatakan wakil British hanya menjaga kepentingan bekas pegawai kerajaan dan elaun yang diterima adalah amat minimum. (Surat daripada Oliver Holt, kepada Lawrance Holt, 6 Ogos 1943, CO 825/33/9 (17-21).

${ }^{14}$ Surat daripada H.S. Lee kepada Chan Kwong Hon, 19 Disember 1944, Folio HSL 121.

${ }^{15}$ Christopher Alan Bayly dan Tim Harper, Forgotten Armies : Britain's Asian Empire and the War with Japan, London: Penguin Books, 2005, hlm. 280-291.

${ }^{16}$ Petisyen daripada 200 orang Cina dari Tanah Melayu kepada Jeneral Wu Te Chen, 12 Jun 1942 , Arkib Kuomintang, Taiwan, Folio Khas 13/4.2.

${ }^{17}$ H. S. Lee kepada Setiausaha Kelab Rotary, Bryant, 27 April 1942, Folio HSL 121. dan List of Evacuee Rotarians in India, issued by the Rotary International, Middle Asia Office, Brabourne Stadium, North, Bombay, Folio HSL 
121. Selain Lee, terdapat lima lagi ahli Kelab Rotary dari Kuala Lumpur. Mereka adalah K.R. Blackwell, John Hands, E.M. Langford, Loke Wan Tho dan H.G. de Siedlieke.

${ }^{18}$ Keratan Akhbar, Folio HSL 121.7.

${ }^{19}$ Shih Sho He (S.H. Shih) adalah konsul China di Kuala Lumpur sebelum berundur ke India, lalu menjadi setiausaha kepada Pesuruhjaya China di New Delhi, dan kemudian dinaikkan kepada wakil Kedutaan China di India . Lee mengekalkan hubungan surat-menyurat dengan Shih sepanjang Lee berada di India. Sila rujuk Surat daripada S.H. Shih kepada H.S. Lee, 22 Mac 1942, Folio HSL 121.3/1.

${ }^{20} \mathrm{Wu}$ Te Chen merupakan pengerusi kerajaan provinsi Kwangtung antara tahun 1937-38. Beliau dilantik sebagai Menteri Luar Negara China Kuomintang Pusat pada tahun 1940, tahun 1941 sebagai pengerusi Persatuan Orang China Laut Selatan dan Majlis Perhubungan Luar Kebangsaan, kemudian Setiausaha Negara KMT. Jeneral Wu pernah melawat Tanah Melayu pada akhir tahun 1940. The Straits Times, 11 Jan. 1941.

${ }^{21}$ Surat daripada HSL kepada Wu Te Chen, 11 April 1942, Folio HSL 121.5/2. Lee berharap dapat menukar sebanyak Rs 400,000 pada kadar yang lebih baik dari kadar yang ditentukan oleh kerajaan, di mana kadar rasmi bank adalah Rs $1=\mathrm{C} \$ 4.50$, tetapi kadar biasa adalah Rs $1=\mathrm{C} \$ 8-\mathrm{C} \$ 10$. Tambahan pula, terdapat kawalan pertukaran asing yang terhad kepada Rs 10,000 seorang untuk dibawa ke China.

${ }^{22}$ Surat daripada K.L. Yuen kepada HSL, 6 April 1942, Folio HSL 121.1/1; Surat daripada K.L. Yuen kepada HSL, 27 April 1942, Folio HSL 121.1/4 ; dan Surat daripada K.L. Yuen kepada HSL, 4 Mei 1942, Folio HSL 121.1/10.

${ }^{23}$ Surat daripada S.H. Shih kepada HSL, 21 Mei 1942, Folio HSL 121.3/12a.

${ }^{24}$ Chan Seng Chin (S.C. Chan), peguam dan anak pertama kepada Chan Kang Swi dari Melaka. Adik lelaki yang ketiga, Chan Seng Kee, berkahwin dengan Tan Kim Tin, anak perempuan pertama Tan Cheng Lock pada tahun 1935. Manakala adik perempuannya yang pertama, Chan Gek Cheow berkahwin dengan Dr Ho Pao Jin, seorang pegawai bank yang terkenal. Sila rujuk The Straits Times, 25 Mei 1927 dan 23 Apr. 1935.

${ }^{25}$ Surat daripada K.L. Yuen kepada H.S. Lee, 10 Jun 1942, Folio HSL 121.1/13.

${ }^{26}$ Surat kepada Wu Te Chen daripada HSL, 13 Jun 1942, Folio HSL 121.5/5.

${ }^{27}$ Surat daripada Yuen kepada Menteri Luar Negara, 17 Jun 1942, Arkib KMT, Folio Khas 13/4.3; Surat daripada Sun Qin kepada Wu Te Chen bahawa urusan penyewaan kepal terbang telah diserah kepada China Airline cawangan Calcutta, 27 Jun 1943, Arkib KMT, Folio Khas 13/4.4; Surat daripada Yuen kepada Jeneral Wu Te Chen, 17 Jun 1942, Arkib KMT, Folio Khas 13/4.5. \& Surat daripada K.L. Yuen kepada H.S. Lee, 2 Julai 1942, Folio HSL 121.1/19. Kos untuk menyewa sebuah kapal terbang adalah Rs 51,502. Yuen menegaskan ini adalah kadar kerajaan (Rs 8 per tan per meter) dan kadar komersial adalah Rs 10 per tan per meter. Manakala kadar penerbangan ke Chungking untuk seorang adalah Rs 1,180. Sila rujuk Surat daripada K.L. Yuen kepada H.S. Lee, 24 Julai 1942, Folio HSL 121.1/24.

${ }^{28}$ Surat daripada H.M. Lee kepada S.H. Shih, 17 Julai 1942, Folio HSL 121.3/33.

${ }^{29}$ Surat daripada Thos. Cook \& Son Limited (Agen Penumpang Asing Am) kepada Konsul China di New Delhi, 14 Oktober 1942, Folio HSL 14.1/3.

${ }^{30}$ Surat daripada K.L Yuen kepada H.S. Lee, 19 Februari 1943, Folio HSL 121.

${ }^{31}$ Surat daripada Shang Chen kepada H.S. Lee, 22 November 1942, Folio HSL 121 dan The Straits Times, 13 Mei 1941. Semasa Lee berjumpa dengan Chiang di Calcutta pada bulan Februari 1942, Shang juga menemani Chiang dalam lawatan tersebut.

${ }^{32}$ Laporan 'yindu guangan ji malaiya huaqiao jianglai zhi lichang (Pandangan terhadap India dan Pendirian Orang Cina Tanah Melayu pada Masa Depan)' oleh H.S. Lee kepada Chiang Kai Shek, 26 Oktober 1942, Arkib KMT, Folio Chiang Kai Shek 002-080106-00072-018.

${ }^{33}$ Lau Pak Khuan (1895-1971), Hakka, pelombong timah dan pengasas Chung Khiaw Bank. Pemimpin Cina yang terkenal di Perak.

${ }^{34}$ Lien Ying Chow (1906-2004), Kantonis, presiden Dewan Perniagaan Cina Singapura pada tahun 1941.

${ }^{35}$ Ho Poh Jin@Ho Pao Jin, Hokkien, pengurus Ho Hong Bank cawangan Melaka dan pemimpin KMT tempatan sebelum perang.

36 Lien Ying Chow, From Chinese Villager to Singapore Tycoon: My Life Story, Singapore: Times Books International, 1994, hlm. 77. Mereka kemudian mengasaskan Overseas Chinese Union Bank di China pada 1943, di mana Lien Ying Chow adalah presiden eksekutif, lembaga pengarah yang lain termasuk Lau Pak Khuan (Perak), Ho Poh Jin (Melaka), Wong Shee Fun (Johor), dan Oh Siow Yam (Singapura).

${ }^{37}$ Surat daripada H.S. Lee kepada K.L. Yuen, 3 Mac 1943, Folio HSL 121.

${ }^{38}$ Chan Kwong Hon (5 Feb 1909- 28 Mei 1978) dilahirkan di Kuala Lumpur, merupakan anak lelaki sulung Chan Chin Mooi. Beliau merupakan pelombong bijih timah dan aktif dalam politik selepas Perang Dunia Kedua.

${ }^{39}$ Surat daripada Chan Kwong Hon kepada H.S. Lee, 2 September 1942, Folio HSL 121. 
${ }^{40}$ Surat daripada H.S. Lee kepada Jin Hai, 22 April 1943, Folio HSL 121.

${ }^{41}$ Surat daripada H.S. Lee kepada Martin, 31 Disember 1942, Folio HSL 121.

${ }^{42}$ Surat daripada H.S. Lee kepada K.L. Yuen, 3 Mac 1943, Folio HSL 121.

${ }^{43}$ Surat daripada H.S. Lee kepada Wu Te Chen, 5 Mac 1943, Folio HSL 121.

${ }^{44}$ Ibid.,dan Surat daripada H.S. Lee kepada Shang Chen, 5 Mac 1943, Folio HSL 121.

${ }^{45}$ Surat daripada Shang Chen kepada H.S. Lee, 15 Mei 1943, Folio HSL 121.

${ }^{46}$ Surat daripada H.S. Lee kepada Shang Chen, 3 Jun 1943, Folio HSL 121.

${ }^{47}$ Surat daripada Shang Chen kepada H.S. Lee, 28 Jun 1943, Folio HSL 121.

${ }^{48}$ Surat daripada Wu Te Chen kepada H.S. Lee, 21 Mei 1943, Folio HSL 121.

${ }^{49}$ Persatuan Orang Cina Laut Selatan (South Seas Chinese Association) telah ditubuhkan pada 10 Mei 1942 di bawah pimpinan Setiausaha Negara KMT, Wu Te Chen. Ia kemudian bertukar nama kepada Pusat Persatuan Orang Cina Seberang Laut dan wujud sehingga kini. Sejarah penubuhan persatuan ini sila rujuk laman web persatuan, http://ocah.org.tw/, tarikh capaian: 30 Ogos 2013.

${ }^{50}$ Surat daripada K.L. Yuen kepada H.S. Lee, 16 Jun 1943, Folio HSL 121.

51 Tan Cheng Lock (5 April 1883-16 Disember 1960), peranakan yang berasal dari Melaka, peladang getah, pemilik bank dan ahli politik. Sila rujuk Alice Scott-Ross, Tun Dato Sir Cheng Lock Tan: a personal profile by his daughter, Singapore: Alice Scott-Ross, 1990; Soh Eng Lim, 'Tan Cheng Lock: His leadership of the Malayan Chinese,' Journal of Southeast Asian History, Jil. 1, No. 1, 1960.; K.G. Tregonning, 'Tan Cheng Lock: A Malayan Nationalist,' Journal of Southeast Asian Studies, Jil. X, No. 1, 1979; Yeo Siew Siang, Tan Cheng Lock: The Straits Legislator and Chinese Leader, Petaling Jaya: Pelanduk Publications, 1990.

${ }^{52}$ Dalam TCL Folio3.024, Tan Cheng Lock menulis kepada Fletcher bahawa"I do not know whether or not you intend to proceed with the formation of the Oversea-Chinese Association as I have not heard from you since about it ; further you are now going to Chungking. ...Re the proposed Oversea-China Association, I have mentioned the idea of forming it to my Chinese friends without making any reference to you whatsoever, but as one coming entirely from myself and they all welcome the proposal. So I believe we [were] on right lines the formation of the association should prove a success."

${ }^{53}$ Neville Wylie (eds.), The Politics and Strategy of Clandestine War: Special Operation Executive, 1940-1946, Oxon: Routledge, 2007, hlm. 11, 193 \& 205; Richard J. Aldrich, Intelligence and the War Against Japan: Britain, America and the Politics of Secret Service, Cambridge: Cambridge University Press, 2000, hlm. $361-362$ \& 372. Pada asalnya pihak British berharap Fletcher boleh menggunakan kenalan beliau untuk menyeludup getah dari Tanah Melayu dan Indo-China yang telah diduduki oleh Jepun melalui pasaran gelap China. Operasi ini kemudian dipelbagaikan bagi meliputi penyeludupan mata wang asing, berlian dan jentera untuk membiayai aktiviti SOE. Force 136 merupakan nama lain bagi SOE di Timur Jauh. Antara ahlinya yang terkenal adalah Lim Bo Seng yang dilantik sebagai Reginal Chief of the (Chinese) Force 136. Beliau dihantar ke Tanah Melayu dan terkorban selepas ditangkap oleh pihak Jepun.

${ }^{54}$ Sila rujuk Nota oleh G.E.J. Gent, 20 Oktober 1943, CO 825/35/15 (42). Tiada maklumat lanjut tentang peranan Fletcher dalam OAC kecuali dalam Surat daripada Tan Cheng Lock kepada Captain Newhouse, 21 Oktober 1943, CO 825/35/15 (41). di mana Tan berkata beliau akan menulis kepada G.E.C. Gent yang berkhidmat di Pejabat Tanah Jajahan tentang apa yang dinasihati oleh Fletcher dan 'I will carry out all his good advice which is for the good of the Chinese.'

55 Tan Siew Sin (27 Mei 1916-March 1988), satu-satunya anak lelaki kepada Tan Cheng Lock. Peranakan yang berasal dari Melaka, menerima pendidikan di Malacca High School, Kolej Raffles di Singapura dan menyertai Meddle Temple di London pada tahun 1938. Selepas berlakunya perang di Eropah, Tan Siew Sin pulang ke Tanah Melayu pada tahun 1939 dan membantu perniagaan keluarganya.

${ }^{56}$ Surat daripada Tan Siew Sin kepada H.S. Lee, 15 Julai 1943, Folio HSL 121.

${ }^{57}$ Surat daripada Tan Siew Sin kepada H.S. Lee, 27 Jun 1943, Folio HSL 121.

${ }^{58}$ Christopher Alan Bayly dan Tim Harper, Forgotten armies: Britain's Asian empire and the war with Japan, hlm. 420-421. Dikatakan daripada 300 penduduk Tanah Melayu di India, 220 orang telah menjadi ahlinya.

${ }^{59}$ John Laycock, peguam British. Sebelum perang merupakan ahli Majlis Perbandaran Singapura. Sila rujuk The Straits Times, 1 Mac. 1956.

${ }^{60}$ Joseph Aaron Elias (1881- 1949) adalah seorang usahawan yang sangat berjaya dan terkenal di dalam masyarakat Yahudi di Singapura. Beliau pernah dianugerahkan Jaksa Pendamai (Justice of Peace) dan berkhidmat sebagai pesuruhjaya Perbandaran Singapura. Sila rujuk Singapore Infopedia, http://infopedia.nl.sg/articles/SIP_1206_200812-05.html, tarikh capaian 31 Ogos 2013. 
${ }^{61}$ Herbert Fancott, berkhidmat dengan Gammon (Malaya) Bhd. di Singapura sejak 1925, terlibat dalam pembinaan tambak Johor. Beliau kemudian menjadi presiden bagi MAI dan pengerusi Dana Bantuan Timur Jauh (Far Eastern Relief Fund). Sila rujuk The Straits Times, 4 Jun 1952.

${ }^{62}$ Christopher Alan Bayly dan Tim Harper, Forgotten armies : Britain's Asian Empire and the War with Japan, hlm. 421. Tan Siew Sin juga memberitahu Lee bahawa dengan masalah yang timbul di antara ahli jawatankuasa MAI, mereka berpendapat tiada apa-apa yang telah dilakukan benar-benar oleh badan ini bagi orang Cina. Sila rujuk Surat daripada Tan Siew Sin kepada H.S. Lee, 15 Julai 1943, Folio HSL 121.

${ }_{64}^{63}$ Surat daripada H.S. Lee kepada Tan Cheng Lock, 21 Julai 1943, Folio HSL 121.

${ }^{64}$ Mengikut Zhang Xiuming, 'A Marginalized Community: The Changes and Development of the Chinese Community in India,' Overseas Chinese History Studies, No. 4, 2008, hlm. 10, orang Cina di India pada 1960-an kebanyakan terlibat dalam industri pembuatan kulit (28\%), kasut (20\%), membuka kedai runcit (10\%), membuat gigi palsu (10\%), tukang kayu atau mekanik (10\%), restoran (5\%), dobi (5\%), gunting rambut (4\%), import eksport (3\%) dan lain-lain (5\%).

${ }^{65}$ Surat daripada H.S. Lee kepada Tan Siew Sin, 20 Julai 1943, Folio HSL 121.

${ }^{66}$ Surat daripada H.S. Lee kepada Tan Siew Sin, 21 Julai 1943, Folio HSL 121. "We know we Malayan Chinese have a common object, then why not let us come together to form a solid body, which, though shall and less pretentious, will nevertheless serve us now and have unlimited scope to work for the benefit of the Chinese in Malaya later." Manakala dalam Surat daripada H.S. Lee kepada Tan Cheng Lock, 21 Julai 1943, Folio HSL 121. Lee seolah-olah membayang bahawa adalah lebih sesuai beliau sendiri dilantik sebagai ketua persatuan ini, "It would, I venture to say, receive more than the goodwill of our Government, if the man at the helm has in the past represented Chinese interests in Malaya and has also some standing in the eyes of our officials."

${ }^{67}$ Surat daripada H.S. Lee kepada Tan Cheng Lock, 21 Julai 1943, Folio HSL 121.

${ }^{68}$ Surat daripada Tan Siew Sin kepada H.S. Lee, 13 Ogos 1943, Folio HSL 121.

${ }^{69}$ Surat daripada H.S. Lee kepada Tan Cheng Lock, 19 Ogos 1943, Folio HSL 121.

${ }^{70}$ Surat terbuka daripada OCA India, 8 September 1943, Folio HSL 121, di mana berita penubuhan OCA telah disiarkan oleh All-India Radio dalam semua buletin berita mereka dengan pelbagai bahasa. Reuters juga melaporkan berita ini.

${ }^{71}$ CO 825/35/15 (39), Antara ahli jawatankuasa OCA yang lain adalah Tan Chin Tuan, Y.C. Foo, Dr. K.W. Tan, Foo Meow Chin, Ng Sen Choy, C.H. Koh, Cheah Phee Phay, Loke Wan Tho, Ong Ee Lim, Ong Peng Hock, Cik Mabel Wong, Puan Lee Choon Guan, Puan Loke Yew, Y.H. Kwong, Gee Tsing Po, Chan Kay Gwan, Chan Yuchai, Tan Thye Choon, Sze Chusian, Chow Chung Lung, Puan K.N. Choy, Wang Chiew Cheng, Dr Choo Teck Guan, dan Puan Ou Kok Boo

${ }^{72}$ Borang pendaftaran kelayakan yang diagihkan oleh OCA, Borang pendaftaran tuntutan harta benda yang diagihkan oleh OCA dan Surat Terbuka OCA, 23 Julai 1943, Folio HSL 121.

${ }^{73}$ Terdapat 30 nama dalam senarai penaja. Selain Tan Cheng Lock (Bangalore) dan Tan Siew Sin, yang lain adalah, Li Boon Tin, Y.H. Kwong (Agen Calcutta), Lim Keng Hor (Agen Bombay), Foo Meow Chin (Agen Mardras), Shimein Huie, Ong Peng Hock, Ng Sen Choy, Puan S. Q. Wong, Loke Wan Tho, Y.C. Foo, Cheah Phee Phay, Dr Choo Teck Guan, Dr Wu Moon-Aung, Chan Kay Gwan, Chan Yuchai (Charlie Chan), Ong Ee Lim, S.K. Chan, C.H. Koh, Cheung Pok Sze, Puan Lee Chun Guan, Madam Lim Chai Hoon (Puan N. Parnell), Sze Chusian, Tan Chwee Pang, Loke Chan Hing, Tan Guan Kai, Cik Nai Shen Hsiu, Lim Tyaung Phwan, dan Thomas Cox.

${ }_{75}^{74}$ Surat daripada Foo Ying Chiew kepada Tan Siew Sin, 31 Oktober 1943. National Archives of India.

${ }^{75}$ Tan Chin Tuan (1908-2005), berasal dari Singapura. Sebelum perang beliau merupakan ahli Straits Chinese British Association, Singapore Municipal Commisioner dan pengarah urusan Oversea-Chinese Banking Corporation (OCBC). Semasa pendudukan Jepun, beliau melarikan diri ke Australia, tiba di India pada September 1943 dan menubuhkan ibu pejabat OCBC di Bombay. Beliau dilantik sebagai timbalan presiden OCA India (1943) dan presiden Malayan Association India pada awal tahun 1945.

${ }_{77}^{76}$ Surat daripada Dr. C. J. Pao kepada Tan Chin Tuan, 4 November, 1943. National Archives of India.

${ }_{78}^{77}$ Surat daripada Tan Cheng Lock kepada Tan Chin Tuan, 12 Disember 1943, National Archives of India.

${ }^{78}$ Surat daripada Saw Hoaikok kepada bapanya, Saw Taik Leong, 23 November 1943, No.29, National Archives of India.

${ }^{79}$ Surat daripada Tunku Abu Bakar kepada Gent, Pejabat Koloni, 14 Oktober 1943, CO 825/35/15 (17).

${ }^{80}$ Surat daripada H.S. Lee kepada Tan Siew Sin, 21 Julai 1943, Folio HSL 121,

${ }^{81}$ Surat daripada H.S. Lee kepada Yeh Nan, 9 November 1943, Folio HSL 121,

${ }^{82}$ Surat daripada H.S. Lee kepada Shang Chen, 27 Disember 1943, Folio HSL 121; Surat daripada Shang Chen kepada H.S. Lee, 7 Februari 1944, Folio HSL 121. 
${ }^{83}$ Surat daripada Chan Kwong Hon kepada H.S. Lee, 24 Mac 1944, Folio HSL 121. Cawangan Chinese Foreign Relations Association ditubuhkan pada awal tahun 1944 di bawah naungan Konsul Jeneral Pao.

${ }^{84}$ Surat daripada Chan Kwong Hon kepada H.S. Lee, 21 April 1944, Folio HSL 121. dan Surat daripada Shih kepada H.S. Lee, 23 Januari 1944, Folio HSL 121.

${ }^{85}$ Bacaan lanjut tenteng Pusat Latihan Ramgarh sila rujuk Charles F. Romanus dan Riley Sunderland, United States Army in World War 2, China-Burma-India Theater, Stilwell's Mission to China, US: Defense Dept., Army, Office of the Chief of Military History, 1953, hlm. 212-220.

${ }^{86}$ Wawancara dengan George Lee, anak lelaki kedua H.S. Lee di Royal Selangor Club, 8 Ogos 2013. George teringat bahawa semasa di India, bapanya tidak pernah meninggalkan keluarganya lebih daripada sebulan.

${ }^{87}$ Misalnya Lao Yusan memberitahu Chan Kwong Hon bahawa kehidupan di Lahore adalah membosankan, oleh itu beliau ingin mencari kerja di Delhi. Surat daripada Chan Kwong Hon kepada H.S. Lee, 28 Disember 1943, Folio HSL 121. Chan Hin Cheung, anak kepada Chan Wing, orang yang terkaya di Kuala Lumpur sebelum perang, juga bersungguh-sungguh mencari kerja. Surat daripada Chan Kwong Hon kepada H.S. Lee, 23 Julai 1944, Folio HSL 121.

${ }^{88}$ Chan ditawarkan Rs 300 sebulan dan bekerja dari 3pm-6.45pm. Surat daripada Chan Kwong Hon kepada H.S. Lee, 21 Feb 1944, Folio HSL 121.

89 Chan King Nui, From Poor Migrants to Millionaire: Chan Wing 1873-1947, Kuala Lumpur: Malaysian Branch of the Royal Asiatic Society, 1997, hlm. 128.

${ }^{90}$ Lao ditawarkan Rs 300 sebulan dan bekerja dari 8.30am kepada 5.30pm untuk $61 \frac{1}{2}$ hari seminggu. Surat daripada Chan Kwong Hon kepada H.S. Lee, 21 Feb 1944, Folio HSL 121.

${ }^{91}$ Loke Tai Wah adalah anak kepada Loke Looi Chiew, pelombong bijih timah dan pemilik ladang getah yang terkenal di Selangor. Beliau bekerja di SOS dengan Rs250 sebulan. The Straits Times, 8 Okt. 1961 \& Surat daripada Chan Kwong Hon kepada H.S. Lee, 14 Mac 1944, Folio HSL 121.

${ }^{92}$ The Straits Times, 13 Sep. 1945.

93 Ibid.

${ }^{94}$ Douglas teringat semasa cuti musim panas, beliau pernah bekerja di limbungan kapal, melakukan kerja-kerja penyelenggaraan ke atas kapal-kapal yang telah dibom oleh tentera Jepun. Beliau dibayar 6 annas sehari dan kebanyakan wang telah dibelanjakan untuk rekod lagu. Sila rujuk Viji Krishnamoorthy, 'Datuk Douglas and Datin Ruby Lee: The Lion and the Jewel', Journal One, Bilangan Julai 1997, hlm. 14-25.

${ }^{95}$ Surat daripada Dr Edmund R. Ronald kepada H.S. Lee, 7 Mei 1942, Folio HSL 121.6/1. Dikatakan hotel yang terbesar di Calcutta pada masa itu adalah Great Eastern dan Grand Hotel. Kadar sewa sehari untuk seorang adalah Rs 18.

${ }^{96}$ Surat daripada Yeh Nan kepada H.S. Lee, 16 November 1943, Folio HSL 121. Di mana kereta pada masa itu bukan hanya sekadar barang mewah, tetapi disebabkan oleh ancaman perang, bilangan kereta yang dijual dalam pasaran adalah terhad dan petrol kereta adalah dibawah kawalan kerajaan. Lee melalui Yeh Nan, berjaya membeli sebuah kereta (BMW 6219) di Bombay. Dengan menggunakan kuasanya sebagai pegawai kerajaan Cina, Lee dapat catuan petrol kereta daripada pihak Lembaga Catuan Bombay.

${ }^{97}$ Surat daripada H.S. Lee kepada S.H. Shih, 3 Ogos 1942, Folio HSL 121.3/36.

${ }^{98}$ Surat daripada S.H. Shih kepada HSL, 25 Jun 1942, Folio HSL 121.3/28.

${ }^{99}$ Surat daripada H.S. Lee kepada Jeneral Shang, 5 Mac 1943, Folio HSL 121.

${ }^{100}$ Woodstock merupakan sekolah berasrama penuh yang tertua di India yang didirikan pada tahun 1854 oleh mubaligh Kristian.

${ }^{101}$ Wynberg juga merupakan sekolah berasrama penuh yang ditubuhkan oleh mubaligh Kristian pada tahun 1888.

${ }^{102}$ Allen School didirikan pada tahun 1926.

${ }^{103}$ Surat daripada K.L. Yuen kepada H.S. Lee, 16 Jun 1943, Folio HSL 121.

${ }^{104}$ Elphinstone College ditubuhkan pada tahun 1856, dan adalah salah satu kolej Universiti Bombay yang paling lama.

${ }^{105}$ Viji Krishnamoorthy, 'Datuk Douglas and Datin Ruby Lee: The Lion and the Jewel,' hlm. 17.

${ }^{106}$ Ruby adalah anak kepada Ong Ee Lim, pemilik panggung wayang di Kuala Lumpur. Panggung wayang yang dimiliki termasuk Ruby Theatre di Ipoh serta Princess Cinema (kemudian ditukar kepada Lido) di Brickfield. Selepas balik ke Tanah Melayu, Douglas dan Ruby masih berhubung antara satu sama lain dan akhirnya berkahwin pada tahun 1947.

${ }^{107}$ Surat jemputan daripada Maharaja Baroda kepada H.S. Lee, 12 Disember 1944, Folio HSL 121. Lee pula menerima jemputan dengan berbalas kepada pihak penganjur yang berpusat di Kelab Sukan Wellingdon. Surat jawapan daripada Lee, 24 Disember 1944, Folio 121. 
${ }^{108}$ Surat daripada Chan Kwong Hon kepada H.S. Lee, 10 Mei 1944, Folio HSL 121.

${ }^{109}$ Children and Misc personal matters, Folio HSL 104/20.

${ }^{110}$ Catatan ringkas tentang pengalaman Lee Xie Chen, pengurus Tai Yau Tin Mines semasa pendudukan Jepun di Tanah Melayu, Folio HSL 162.

${ }_{111}^{11}$ Akaun-akaun You Tai Timber Kongsi, Folio HSL 162.

${ }^{112}$ Form of registration of Overseas Chinese evacuated from Malaya, Netherland East Indies and other Countries to India, Folio HSL 121.2.

${ }^{113}$ Bacaan lanjut tentang perancangan British terhadap Tanah Melayu selepas perang sila rujuk C. M. Turnbull, 'British Planning for Post-war Malaya,' Journal of Southeast Asian Studies, Jil. V, No. 2, 1974, hlm. 239-254.

${ }^{114}$ Menurut Lee, Victor Purcell merupakan 'a personal friend' dan mereka belajar di Cambridge pada masa yang sama. Sila rujuk Surat H.S. Lee kepada G.S. Rawling, Far Eastern Bureau, British Ministry of Information, New Delhi, 4 Januari 1943, Folio HSL 121.

${ }^{115}$ Pengaruh Purcell dalam pembentukan Malayan Union adalah amat besar, terutamanya dasar British terhadap orang Cina selepas perang. Sila rujuk Christopher Alan Bayly dan Tim Harper, Forgotten Wars: the End of Britain's Asian Empire, hlm. 99.

${ }^{116}$ Surat daripada Chan Kwong Hon kepada H.S. Lee, 30 April 1945, Folio HSL 121.

${ }^{117}$ Surat daripada H.S. Lee kepada Shih, 11 Disember 1944, Folio HSL 121 dan Surat daripada Chan Kwong Hon kepada HSL, 27 Julai 1945, Folio HSL 121.

${ }_{118}^{118}$ Memorandum: Evacuees from Malaya in India, 13 Februari 1945, CO 825/46/11.

${ }^{119}$ Menurut Lee, beliau kembali sebagai komander kapal, SS. Dilwark [Dilwara]. Disebabkan keadaan yang tidak menentu selepas perang, keluarganya masih berada di India dan kembali ke Tanah Melayu selepas beberapa bulan kemudian.

${ }^{120}$ Su Yin Lee, Rock Solid: The Corporate Career of Tan Chin Tuan, Singapore: Landmark Books, 2006, hlm. 62.

121 T.R.P. Dawson, Tan Siew Sin: The Man from Malacca, Singapore: Donald Moore Press Ltd, 1969, hlm. 1.

122 K.G. Tregonning, 'Tan Cheng Lock: A Malayan Nationalist,' Journal of Southeast Asian Studies, Jil. X, No. 1, 1979, hlm. 50.

${ }^{123}$ Min Sheng Pao, 17 Nov. 1945. Dewan Perhimpunan Cina Selangor telah menyambung semula aktiviti persatuan dengan mengadakan mesyuarat ahli jawatankuasa yang pertama pada 19 November 1945, di mana Lee telah dilantik semula sebagai naib presiden.

${ }_{124}$ Min Sheng Pao, 25 Nov. 1946.

${ }^{125}$ Namun sebelum Pasukan 136 mengambil apa-apa tindakan, pihak Jepun telah menyerahkan diri manakala bagi Lim Bo Seng, sebaik sahaja beliau dihantar balik ke Tanah Melayu beliau telah ditangkap oleh pihak Jepun dan meninggal dunia di penjara. Selepas perang, Lim dianugerahkan pangkat Major Jeneral oleh kerajaan China dan sebuah tugu peringatan telah didirikan di Singapura untuk mengenal pengorbanan beliau. Sila rujuk Tan Chong Tee, Story of a WWII Resistance Fighter: Force 136, trans., Lee Watt Sim \& Clara Show, Singapore: Asiapac Publication, 1995. Sejak akhir-akhir ini sebuah komik telah dihasilkan untuk mengingati beliau. Sila rujuk Clara Show dan John Dinamic Chu, Lim Bo Seng: Singapore's Best-known War Hero, Singapore: Asiapac, 1998.

${ }^{126}$ Bacaan selanjutnya tentang keadaan pentadbiran Jepun di Tanah Melayu, sila rujuk Yoji Akashi, 'Japanese Policy Towards The Malayan Chinese 1941-1945', dalam Wolf Mendl (eds.), Japan and South East Asia, London: Routledge, 2001; Paul H. Kratoska, The Japanese occupation of Malaya : a Social and Economic History, Honolulu: University of Hawai'i Press, 1997; Paul H Kratoska (eds.), Malaya and Singapore during the Japanese Occupation, Journal of Southeast Asian Studies Special Publication Series, Singapore: The National University of Singapore, 1995.

${ }^{127}$ Cheah Boon Kheng, Red Star over Malaya: Resistance and Social Conflict During and After the Japanese Occupation of Malaya, 1941-1946, 3rd ed. Singapore: Singapore University Press, 2003, hlm. 20-24.

${ }^{128}$ Sila rujuk Li Ye Lin (eds.), Fengnajin ziliao xuanbian (Bahan-bahan Pilihan Sumbangan Kewangan), Kuala Lumpur: Centre for Malaysian Chinese Studies, 2000.

${ }^{129}$ Fujio Hara, 'The Japanese Occupation of Malaya and the Chinese Community', dalam Paul H Kratoska (eds.), Malayan and Singapore during the Japanese Occupation, Singapore: National University of Singapore, 1995, hlm. 52.

${ }^{130}$ Ibid., hlm. 53.

${ }^{131}$ Untuk Kajian tentang jangka masa ini sila rujuk Cheah Boon Kheng, Red Star over Malaya: Resistance and Social Conflict During and After the Japanese Occupation of Malaya, 1941-1946. 